\title{
Physiologic Regulation of Atrial Natriuretic Peptide Receptors in Rat Renal Glomeruli
}

\author{
Barbara J. Ballermann, Richard L. Hoover, Morris J. Karnovsky, and Barry M. Brenner \\ Laboratory of Kidney and Electrolyte Physiology, Brigham and Women's Hospital, and Departments of Medicine and Pathology, \\ Harvard Medical School, Boston, Massachusetts 02115
}

\begin{abstract}
Isolated rat renal glomeruli and cultured glomerular mesangial and epithelial cells were examined for atrial natriuretic peptide (ANP) receptors, and for ANP-stimulated cyclic guanosine monophosphate (cGMP) generation. In glomeruli from normal rats, human (1-28) ${ }^{125} \mathrm{I}-\mathrm{ANP}$ bound to a single population of high affinity receptors with a mean equilibrium dissociation constant of $0.46 \mathrm{nM}$. Human (1-28) ANP markedly stimulated cGMP generation, but not cAMP generation in normal rat glomeruli. Analogues of ANP that bound to the glomerular ANP receptor with high affinity stimulated CGMP accumulation, whereas the (13-28) ANP fragment, which failed to bind to the receptor, was devoid of functional activity. Cell surface receptors for ANP were expressed on cultured glomerular mesangial but not epithelial cells, and appreciable ANP-stimulated cGMP accumulation was elicited only in mesangial cells. $\sim 12,000$ ANP receptor sites were present per mesangial cell, with an average value for the equilibrium dissociation constant of $0.22 \mathrm{nM}$. Feeding of a low-salt diet to rats for 2 wk resulted in marked upregulation of the glomerular ANP receptor density to a mean of $426 \mathrm{fmol} / \mathrm{mg}$ protein, compared with $116 \mathrm{fmol} / \mathrm{mg}$ in rats given a high-salt diet. A modest reduction in the affinity of glomerular ANP receptors was also observed in rats fed the lowsalt diet. ANP-stimulated cGMP generation in glomeruli did not change with alterations in salt intake. We conclude that high salt feeding in the rat results in reduced glomerular ANP receptor density relative to values in salt restricted rats. Furthermore, the mesangial cell is a principal target for ANP binding in the glomerulus.
\end{abstract}

\section{Introduction}

A growing body of experimental evidence suggests that atrial myocytes synthesize and release a peptide hormone important in the regulation of extracellular fluid volume. Mammalian atria contain characteristic secretory granules (1), the number of which correlates inversely with dietary salt intake (2). Extracts of mammalian atria, but not ventricles, induce marked diuresis and natriuresis when infused systemically in rats (3-5) and dogs (6), or intra-arterially into isolated, perfused kidneys $(7,8)$. Natriuretic peptides ( 21 amino acids and longer) have been isolated from atria of rodents and humans, and share a nearly homol-

Address reprint requests to Dr. Ballermann, Royal Victoria Hospital, 687 Pine Avenue West, Montreal, Quebec, Canada H3A 1 Al.

Received for publication 24 May 1985.

J. Clin. Invest.

(C) The American Society for Clinical Investigation, Inc.

0021-9738/85/12/2049/08 \$1.00

Volume 76, December 1985, 2049-2056 ogous amino acid sequence at the carboxy terminus (9-11). Natriuretic activity resides in a 17 -amino acid ring formed by a disulfide bridge (12), and the $\mathrm{COOH}$-terminal Phe-Arg appears necessary for full biologic potency $(13,14)$. The DNA that encodes atrial natriuretic peptides (ANP) ${ }^{1}$ has been cloned (15), and the gene structure for the larger ANP precursor has been elucidated $(11,16,17)$. Reduction of the diuretic and natriuretic response to an acute volume load by right atrial appendectomy first suggested a role for the atrial factor in the physiologic response to volume expansion (18). Subsequently, release of natriuretic factor by isolated heart preparations in response to right atrial distension was demonstrated by bioassay (19) and radioimmunoassay (20). The presence of immunoreactive ANP in rat plasma, with concentrations ranging from $\sim 20$ to 550 pM (20-22), and an increase of circulating ANP levels in response to acute volume expansion (20), have been reported.

The mechanisms by which ANP increases renal salt and water excretion are as yet unclear. Vascular effects have been demonstrated most consistently, whereas evidence for direct actions on tubule epithelium is not convincing at this time (23-25). In vitro, ANP causes precontracted vascular and nonvascular smooth muscle to relax $(26,27)$ with the vascular response independent of functional endothelium, which suggests a direct action of ANP on smooth muscle cells (28). When infused systemically in rats $(5,29)$ and dogs $(6,30)$, ANP reduces mean arterial pressure, in keeping with vasorelaxant activity. In the isolated, perfused kidney, ANP antagonizes the constrictor effects of angiotensin II, norepinephrine, and vasopressin, although an increase in renal vascular resistance is seen in this system when ANP alone is administered (8). In anesthetized rats and dogs, ANP infusion leads to a large increase in glomerular filtration rate with relative constancy of the renal plasma flow rate, thus markedly augmenting filtration fraction $(5,6,30,31)$. Glomerular micropuncture studies indicate that the alterations in glomerular filtration dynamics are largely the result of afferent arteriolar dilatation, accompanied by a small rise in efferent arteriolar resistance (32).

Binding sites for ANP have been characterized in crude membranes prepared from whole kidney homogenates and from aortic smooth muscle (33), in membranes of bovine adrenal glomerulosa (34), and in intact bovine aortic smooth muscle and endothelial cells (35). Natriuretic peptides stimulate cyclic guanosine monophosphate (cGMP) accumulation in intact tissues $(28,36)$, and augment particulate guanylate cyclase activity in membrane fractions (37), which has led some investigators to postulate that ANP receptors are coupled to this enzyme and that cGMP is the second messenger mediating ANP action (37).

Since the glomerulus is a major renal site of ANP action,

1. Abbreviations used in this paper: ANP, atrial natriuretic peptide; CGMP, cyclic guanosine monophosphate; hANP, human ANP; ${ }^{125} \mathrm{I}-\mathrm{hANP},{ }^{125} \mathrm{I}-$ labeled hANP. 
we now report the characteristics of renal glomerular ANP receptors using radioligand binding techniques and cGMP accumulation as the measured physiological response. We show localization of ANP receptors to the cell surface of cultured renal glomerular mesangial, but not epithelial, cells and the regulation of glomerular ANP receptor density in response to dietary salt excess.

\section{Methods}

Animal preparation. Male Sprague-Dawley rats (Charles River Breeding Laboratories, Wilmington, MA) weighing 225-300 g were maintained either on standard rat chow (Ralston Purina Co., St. Louis, MO) or on a low-salt diet (TD 83482; Teklad, Madison, WI). Mild salt depletion was induced by a single intraperitoneal injection of $10 \mathrm{mg} / \mathrm{kg}$ furosemide (Hoechst-Roussel, Somerville, NJ) followed by feeding of the low-salt diet for 10-14 d. High-salt rats were given 1\% saline drinking water and the same low-salt chow. During the second week on the high- or lowsalt intake, six rats from each group were placed into individual metabolic cages, urine was collected for a 24 -h period, and urine sodium concentrations were determined by flame photometry.

Tissue preparation. 1 Glomeruli were isolated by methods modified from those described by Misra (38). Rats were killed by decapitation, exsanguinated, and their kidneys were placed into ice-cold phosphatebuffered saline (PBS). Kidneys were bisected, the medulla, papilla, and capsule were removed, and the resulting cortical rims were finely minced with a razor blade. The tissue was pressed through a stainless steel sieve with a pore size of $104 \mu \mathrm{m}$, and then rinsed from the undersurface through stacked sieves with sequential pore sizes of 180,150 , and $75 \mu \mathrm{m}$. Glomeruli retained on the $75-\mu \mathrm{m}$ sieve were collected in a $50-\mathrm{ml}$ centrifuge tube and washed three times by centrifugation, twice in PBS and the third time in ice-cold Hank's balanced salt solution (HBSS). After the last centrifugation, glomeruli from the kidneys of one rat were suspended in exactly $5.0 \mathrm{ml}$ of HBSS, and a $400-\mu \mathrm{l}$ aliquot was taken for protein determination by the method of Lowry et al. (39). For binding studies, the glomerular suspension was then adjusted to the final assay buffer of HBSS (in mM: $\mathrm{NaCl}, 137 ; \mathrm{KCl}, 5.4 ; \mathrm{KH}_{2} \mathrm{PO}_{4}, 0.44 ; \mathrm{Na}_{2} \mathrm{HPO}_{4}, 0.33$; $\mathrm{MgSO}_{4}, 0.40 ; \mathrm{MgCl}_{2}, 0.50 ; \mathrm{CaCl}_{2}, 1.25$; and $\mathrm{NaHCO}_{3}, 4.0$; at pH 7.4) containing bovine serum albumin (BSA) $0.20 \mathrm{~g} / \mathrm{dl}$; glucose, $5.5 \mathrm{mM}$; Hepes, $10 \mathrm{mM}$; bacitracin, $1 \mathrm{mM}$; and phenylmethylsulfonyl fluoride, $1 \mathrm{mM}$. For cyclic nucleotide studies, glomeruli were isolated in ice-cold

\section{Human (1-28) ANP}

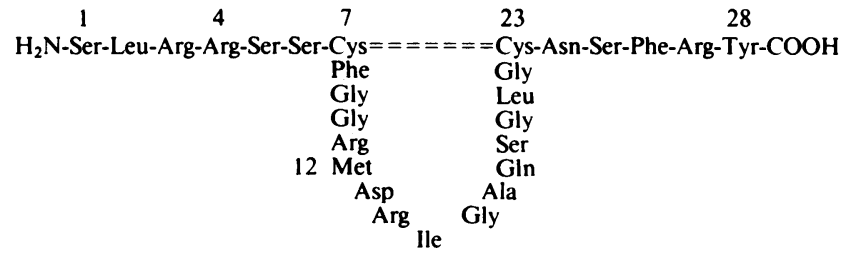

SCHEME I

Table I. Correlation between Receptor Binding and Stimulation of cGMP Generation by Various ANP Analogues

\begin{tabular}{lll}
\hline & Receptor binding & cGMP generation \\
\hline Human (1-28) ANP ${ }^{12}$ Met & Yes & Yes \\
Rat (1-28) ANP ${ }^{12}$ lle & Yes & Yes \\
Rat (4-27) ANP (Auriculin) & Yes & Yes \\
Human (7-28) ANP & Yes & Yes \\
ANP (13-28) fragment & No & No \\
\hline
\end{tabular}

HBSS, washed once by centrifugation, and resuspended in the same assay buffer lacking bacitracin and phenylmethylsulfonyl fluoride.

Cell culture. Glomerular mesangial and epithelial cells were cultured as described previously $(40,41)$. In brief, glomeruli from 50-75-g SpragueDawley rats were isolated in sterile HBSS buffered with $15 \mathrm{mM}$ Hepes, followed by incubation for $45 \mathrm{~min}$ at $37^{\circ} \mathrm{C}$ in HBSS containing $1 \mathrm{mg} /$ ml collagenase (CSL II; Worthington Diagnostics Div., Millipore Corp., Freehold, NJ). Glomeruli then were sedimented by centrifugation, resuspended in $5 \mathrm{ml}$ of calcium-free and magnesium-free HBSS containing $0.5 \mathrm{mg} / \mathrm{ml}$ trypsin and $0.2 \mathrm{mg} / \mathrm{ml}$ EDTA (trypsin/EDTA) (Gibco, Grand Island, NY), and incubated at $37^{\circ} \mathrm{C}$ for $15 \mathrm{~min}$. The cells were sedimented and resuspended in RPMI 1640 medium containing 20\% supplemented calf serum (SCS), $1 \mathrm{U} / \mathrm{ml}$ insulin, $100 \mathrm{U} / \mathrm{ml}$ penicillin, $100 \mu \mathrm{g} / \mathrm{ml} \mathrm{strep-}$ tomycin, and $0.25 \mu \mathrm{g} / \mathrm{ml}$ amphotericin $B$ and diluted $1: 1$ with conditioned medium (Dulbecco's modified Eagle's medium [DME] + 10\% SCS), harvested from Swiss 3T3 cells in the log phase of growth. The cells were plated on $100-\mathrm{mm}$ plastic culture plates, and incubated at $37^{\circ} \mathrm{C}$ in a humidified atmosphere of $5 \% \mathrm{CO}_{2}$ and $95 \%$ air. Cells were fed with fresh medium every $2 \mathrm{~d}$. When outgrowth from glomeruli was nearly confluent 5-7 d later, cells were detached and plated at a density of $\sim 100$ cells/ $\mathrm{ml}$. Single clones formed within $7 \mathrm{~d}$ and were isolated and passaged using cloning cylinders. Cloned epithelial cells were propagated on collagen matrix, prepared by combining rat tail collagen (42) with $10 \times$ concentrated RPMI 1640, 9:1 (vol/vol), which was neutralized with $0.1 \mathrm{~N} \mathrm{NaOH}$. Epithelial cells were grown in Kl-5 medium (DME: Ham's F 10 Medium, 1:1, vol/vol; containing 5\% Nu-Serum [Collaborative Research, Inc., Waltham, MA] supplemented with $5 \mu \mathrm{g} / \mathrm{ml}$ insulin, $5 \mu \mathrm{g} / \mathrm{ml}$ transferrin, $25 \mathrm{ng} / \mathrm{ml}$ prostaglandin $\mathrm{E}_{1}, 5 \mathrm{pM}$ triiodythyronine, $50 \mathrm{nM}$ hydrocortisone, and $10 \mathrm{nM}$ sodium selenite). For the purpose of radioreceptor and CGMP accumulation studies, epithelial cells were plated on plastic culture dishes coated with a thin collagen film that did not contain RPMI medium. Mesangial cells were propagated on plastic culture plates, in RPMI 1640 medium containing $20 \%$ SCS lacking amphotericin B and insulin. Radioreceptor and CGMP accumulation studies were done with confluent monolayers of glomerular epithelial and mesangial cells between the 12 th and 20th passages, using the same assay medium as that for isolated glomeruli, detailed above.

Receptor binding studies. The ${ }^{125}$ I-labeled human 1-28 ANP sequence ( ${ }^{125}$ I-hANP) and the homologous unlabeled peptide (hANP) were used for radioreceptor studies (Scheme I). Rat (1-28 and 4-27) ANP, human (7-28) ANP, and the (13-28) ANP fragment were also examined (Table I). Synthetic radiolabeled and unlabeled peptides were purchased from Peninsula Laboratories, Inc. (Belmont, CA).

For glomerular studies, ${ }^{125}$ I-hANP (specific activity, 1,000-1,300 Ci/ mmol) and appropriate concentrations of unlabeled ANP were placed into borosilicate glass tubes in a volume of $100 \mu \mathrm{l}$, and the reaction was initiated by the addition of $400 \mu$ lof the glomerular suspension. Incubation was in an ice-water bath for $120 \mathrm{~min}$. Bound radioactivity was separated from free within $10 \mathrm{~s}$ by suction-filtration through $3 \times 3-\mathrm{cm}$ squares of nylon mesh, pore size $25 \mu \mathrm{m}$ (Tetko Inc., Elmsford, NY), followed by four washings with ice-cold PBS containing $0.2 \mathrm{~g} / \mathrm{dl}$ BSA. Binding was not altered by continuous washing for up to $60 \mathrm{~s}$. Nonspecific binding was defined as radioactivity bound in the presence of saturating concentrations $(0.1 \mu \mathrm{M})$ of unlabeled ANP and represented $2-5 \%$ of total radioactivity. Binding was not further reduced by higher (up to 10 $\mathrm{mM}$ ) concentrations of unlabeled hANP. Radioactivity was counted in a gamma counter (Autologic; Abbott Laboratories, Irving, TX) with $72 \%$ efficiency. To determine association rates, glomeruli were incubated with $25-75 \mathrm{pM}^{125} \mathrm{I}-\mathrm{hANP}\left(2.5-8.0 \times 10^{4} \mathrm{dpm} / 500 \mu \mathrm{l}\right)$ for varying time periods up to $240 \mathrm{~min}$. Dissociation rates were studied at $0^{\circ} \mathrm{C}$ and $24^{\circ} \mathrm{C}$ by adding $0.1 \mu \mathrm{M}$ unlabeled ANP at binding equilibrium and determining the remaining radioactivity as a function of time up to $120 \mathrm{~min}$. In competitive binding inhibition studies, glomeruli were incubated with 25-75 pM ${ }^{125} \mathrm{I}-\mathrm{hANP}(2.5-8.0 \mathrm{dpm} / 500 \mu \mathrm{l})$ and $50-5,000 \mathrm{pM}$ unlabeled hANP or ANP analogues. In the absence of unlabeled ANP, 5-10\% of total added radioactivity was specifically bound to glomeruli. Studies using increasing concentrations $(100-2,000 \mathrm{pM})$ of radiolabeled hANP were done after the specific activity of ${ }^{125}$ I-hANP was adjusted to 200 - 
$250 \mathrm{Ci} / \mathrm{mmol}$. Radioactivity added ranged from $2.2-56 \times 10^{4} \mathrm{dpm} / 500$ $\mu \mathrm{l}$. After incubation with glomeruli, radiolabeled ANP was $94 \%$ intact as assessed by rebinding experiments $(n=2)$.

For studies with glomerular mesangial and epithelial cells, confluent monolayers were washed four times with ice-cold HBSS and overlaid with assay buffer containing $25-75 \mathrm{pM}^{125}$ I-hANP $\left(2.5-8.0 \times 10^{4} \mathrm{dpm} /\right.$ $500 \mu \mathrm{l})$ and appropriate concentrations of unlabeled hANP. Incubation was for $180 \mathrm{~min}$ on a bed of crushed ice. Bound radioactivity was separated from free radioactivity by aspirating the supernatant, and then washing four times with ice-cold PBS containing $0.2 \mathrm{~g} / \mathrm{dl}$ BSA. Cell monolayers remained intact after the final wash as judged by microscopy. Cells were dissolved in $500 \mu \mathrm{l} 1.0 \mathrm{~N} \mathrm{NaOH}$ and cell-associated radioactivity was counted. Specific binding in the absence of unlabeled ANP ranged from 7.5 to $20 \%$ of total added radioactivity for mesangial cells, and nonspecific binding for epithelial and mesangial cells represented $1-2 \%$ of total added radioactivity. Cell numbers for three replicate wells were determined using a hemocytometer.

Cyclic nucleotide determinations. Freshly isolated glomeruli were preincubated at $37^{\circ} \mathrm{C}$ for $15 \mathrm{~min}$ in $400 \mu \mathrm{l}$ assay buffer. Isobutylmethylxanthine then was added in a volume of $50 \mu$ followed exactly 2 min later by hANP or ANP analogues (Scheme I and Table I) in $50 \mu$ lo achieve concentrations varying from 0.1 to $100 \mathrm{nM} ; 50 \mu$ l of buffer alone was added for base-line levels. The reaction was stopped at exactly $60 \mathrm{~s}$ by adding $500 \mu \mathrm{l} 12 \mathrm{~g} / \mathrm{dl}$ trichloroacetic acid, and sonicating. In timed experiments cGMP accumulation was maximal at $30 \mathrm{~s}$ and remained stable for up to $2.5 \mathrm{~min}$. The precipitated protein was sedimented at $2,000 \mathrm{~g}$ for $15 \mathrm{~min}$, and the supernatant was extracted five times with 2 volumes of water-saturated ethyl ether followed by evaporation to complete dryness at $80^{\circ} \mathrm{C}$ under a stream of air. The dried samples were resuspended in $500 \mu \mathrm{l}$ of $50 \mathrm{mM}$ acetate buffer, $\mathrm{pH}$ 7.4. The cyclic nucleotides in 100- $\mu$ l aliquots were acetylated and their concentrations were determined by radioimmunoassay with commercially available assay kits (New England Nuclear, Boston, MA).

Confluent mesangial and epithelial cell monolayers were washed with HBSS, followed by preincubation with buffer alone at $37^{\circ} \mathrm{C}$ for $15 \mathrm{~min}$. $1 \mathrm{mM}$ isobutylmethylxanthine then was added, followed 2 min later by hANP or buffer. We stopped the reaction at $60 \mathrm{~s}$ by aspirating the supernatant and precipitating cell protein with $6 \%$ trichloroacetic acid. Cells were scraped from the culture plates and placed into borosilicate glass test tubes. Cells were sonicated and samples processed as described above for isolated glomeruli.

Data analysis. Results are presented as the mean \pm standard error of the mean for separate experiments. The unpaired Student's $t$ test was used for statistical analysis. Binding data were calculated by Scatchard analysis (43) or with the LIGAND program (44).

\section{Results}

In isolated glomeruli from normal rats, specific binding of 25$75 \mathrm{pM}^{125} \mathrm{I}-\mathrm{hANP}$ at $0^{\circ} \mathrm{C}$ reached equilibrium at $60-90 \mathrm{~min}$ of incubation. Competitive equilibrium binding experiments are shown in the left panel of Fig. 1. The human $\left(\mathrm{Met}^{12}\right)$ and rat (Ile ${ }^{12}$ ) 1-28 atrial peptides competed equally for ${ }^{125} \mathrm{I}-\mathrm{hANP}$ binding to isolated glomeruli. Also shown, the 4-27 fragment of rat ANP (Auriculin) and the 7-28 fragment of human ANP were equipotent as compared with the 28 -amino acid peptides; however, the 13-28 ANP fragment, devoid of the ring structure formed by the $\left(\mathrm{Cys}^{7}-\mathrm{Cys}^{23}\right)$ disulfide bridge, did not compete in the binding assay up to concentrations of $10^{-6} \mathrm{M}$. The unrelated peptide angiotensin II (Fig. 1), and dopamine (data not shown) also failed to compete for ${ }^{125} \mathrm{I}-\mathrm{hANP}$ binding. Competitive binding inhibition data from experiments with unlabeled hANP were subjected to LIGAND analysis (44), which afforded a best fit to a single affinity binding model, and yielded a mean value for the equilibrium dissociation constant $\left(K_{d}\right)$ of $0.46 \pm 0.08 \mathrm{nM}$ $(n=3)$.

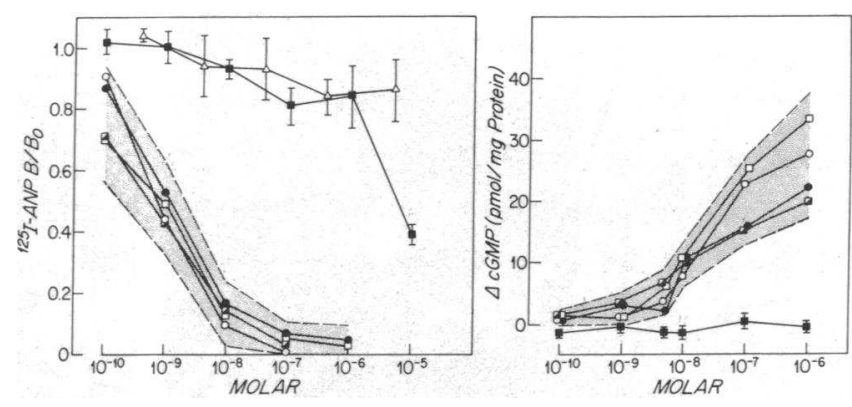

Figure 1. Competitive binding inhibition (left) and ANP-stimulated cyclic GMP generation (right) in isolated glomeruli. Human ANP (128), o; rat ANP (1-28), 口; rat ANP (4-27), 口; human ANP (7-28), ๑; ANP fragment (13-28), $\approx$; angiotensin II, $\Delta$. The shaded areas enclose the standard errors for the data points within them.

In isolated glomeruli from normal rats, hANP markedly stimulated accumulation of cyclic GMP, with a threshold between 0.5 and $1.0 \mathrm{nM}$, and increasing stimulation up to concentrations of $0.1 \mu \mathrm{M}$, as shown in the right panel of Fig. 1. The different ANP analogues that competed in the receptor binding assay also stimulated CGMP accumulation, whereas the 13-28 ANP fragment, which failed to bind to the receptor, was without effect on glomerular cGMP levels (Fig. 1). Although hANP potently stimulated cGMP generation in isolated glomeruli, no increase from base-line cAMP levels was detected up to hANP concentrations of $0.1 \mu \mathrm{M}$. Data for the accumulation of the two cyclic nucleotides in glomeruli, in response to hANP are shown in Fig. 2. Base-line values for CGMP and cAMP content in normal glomeruli were $0.81 \pm 0.04$ and $24.3 \pm 3.1 \mathrm{pmol} / \mathrm{mg}$ protein, respectively $(n=3)$.

To begin to identify the component cells of the glomerulus that express ANP receptors, we examined cloned, homogeneous glomerular mesangial, and epithelial cells for ANP binding. The morphologic characteristics of the two cell types in culture are shown in Fig. 3. Studies were done with intact cell monolayers, on ice, with a buffer closely resembling the composition of extracellular fluid, to assure that the cells remained intact, and that only cell surface receptors were being labeled with ${ }^{125} \mathrm{I}$ hANP. In intact mesangial cell monolayers $\left(6.0 \pm 0.7 \times 10^{5}\right.$ cells/ plate, $n=6$ ), specific ${ }^{125} \mathrm{I}$-hANP binding was demonstrated, with mean values for the receptor density of $19.8 \pm 5.3 \mathrm{fmol} / 10^{6}$ cells, and the $K_{\mathrm{d}}$ of $0.22 \pm 0.05 \mathrm{nM}(n=6)$, as determined by LIGAND analysis of competitive binding-inhibition data. No specific



Figure 2. ANP-stimulated cyclic nucleotide accumulation in rat glomeruli. Cyclic nucleotide generated in the presence of ANP (Cyclic N)/Base-line cyclic nucleotide content (Cyclic $\mathbf{N}_{\mathbf{0}}$ ), cGMP (O), cAMP (•). 

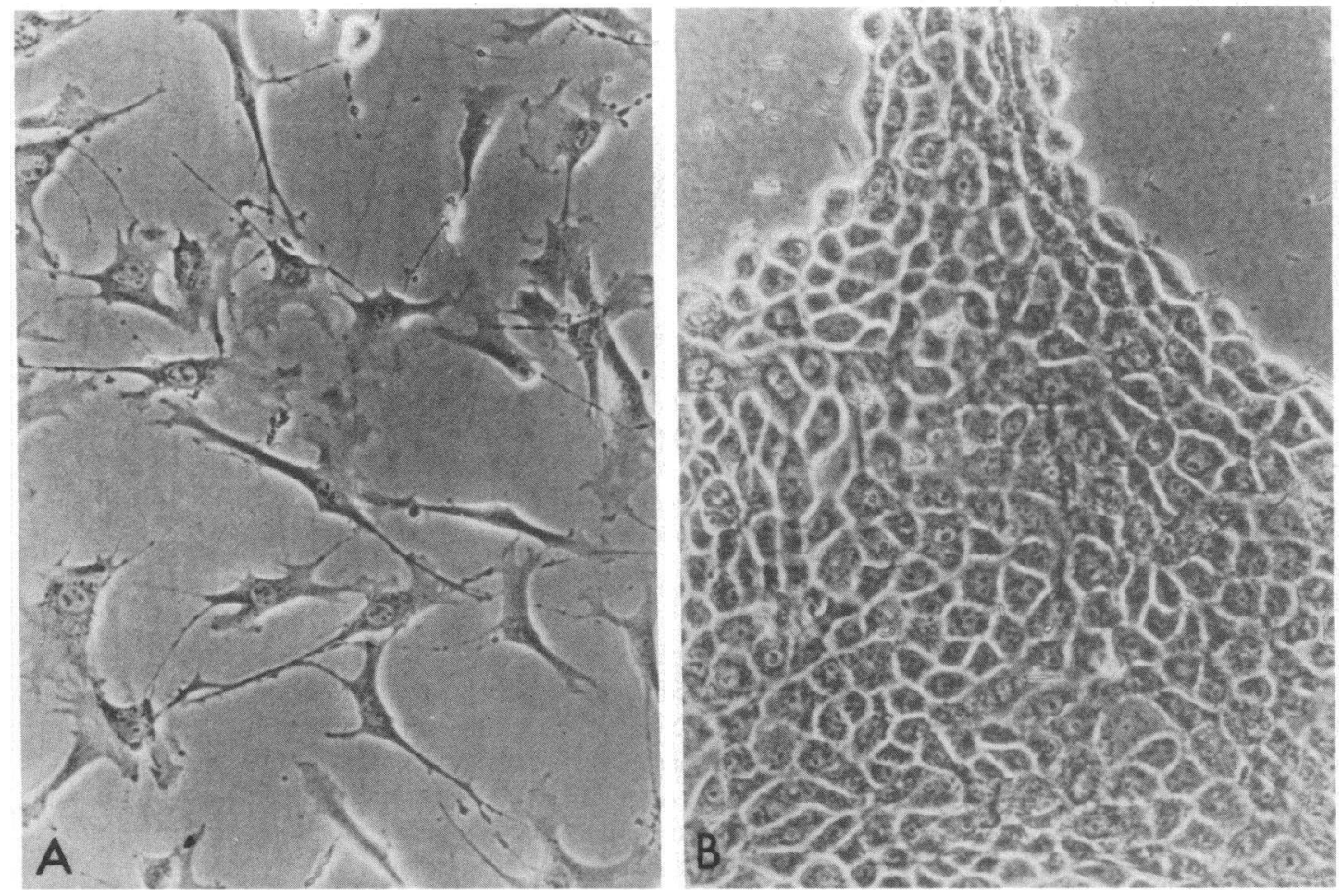

Figure 3. Morphologic characteristics of cultured glomerular mesangial $(A)$ and epithelial $(B)$ cells. Magnification $\times 200$.

binding of ${ }^{125} \mathrm{I}-\mathrm{hANP}$ was detected in monolayers of glomerular epithelial cells with a mean of $1.6 \pm 0.3 \times 10^{6}$ cells/plate $(n=4)$. Competitive binding-inhibition data from one representative experiment, in which the radiolabeled hANP concentration and the cell concentration were nearly identical for the two cell types, is shown in the left panel of Fig. 4. Although not shown, specific hANP binding to glomerular mesangial cells was completely reversed within 5 min of lowering the medium pH to 4.5 , confirming binding to cell surface receptors.

To determine whether ANP functional responsiveness paralleled the binding data in the two cell types, hANP-stimulated cGMP accumulation was measured. In mesangial cells, there was a concentration-dependent increase in CGMP accumulation from base-line levels of $0.95 \pm 0.31$ to $18.25 \pm 1.25 \mathrm{pmol} / 10^{6}$ cells at $0.1 \mu \mathrm{M}$ ANP, while cell-associated cGMP rose from $0.21 \pm 0.02$ to $2.62 \pm 0.66 \mathrm{pmol} / 10^{6}$ cells in epithelial cells. Thus, although hANP stimulated cGMP accumulation in both cell types, this functional response was considerably greater in mesangial than in epithelial cells (Fig. 4, right).

To ascertain whether the density of glomerular ANP receptors is physiologically regulated, ANP receptor equilibrium binding parameters were compared in glomeruli harvested from rats fed either a low- or a high-salt diet for 10-14 d. In glomeruli isolated from rats fed the low-salt diet, ANP receptor density, determined by competitive binding inhibition studies, was nearly fourfold higher, at $385 \pm 37 \mathrm{fmol} / \mathrm{mg}$ protein compared with $118 \pm 14 \mathrm{fmol} / \mathrm{mg}$ in glomeruli from rats fed the high-salt diet $(P<0.001, n=7)$. Mean values for the $K_{\mathrm{d}}$ were $0.94 \pm 0.14 \mathrm{nM}$ in glomeruli from rats fed the low-salt diet and $0.48 \pm 0.06 \mathrm{nM}$ in rats receiving the high-salt diet $(P<0.01, n=7)$, indicating a lower affinity for ANP binding to receptors in glomeruli from low-salt rats. The shift in affinity in glomeruli from low-salt rats was not due to the appearance of a second population of low affinity receptors, as LIGAND analysis consistently gave a best fit with a one-affinity binding model for low- and high-salt states, even when 20 separate concentrations spanning two logs of unlabeled hANP (0.04-6.0 nM) were studied ( $n=4$ /group). Scatchard plots for one representative experiment, comparing glomeruli from rats given low- and high-salt diets are shown in Fig. 5. The linear plots illustrate that single populations of receptors are being detected in each case.

The interaction between glomerular receptors and atrial natriuretic peptide was also assessed by studying specific binding with increasing concentrations of labeled hANP at a constant specific activity. This method reduces the likelihood of underestimation of the receptor binding affinity that can occur in competitive studies if concentrations of radioligand or receptor
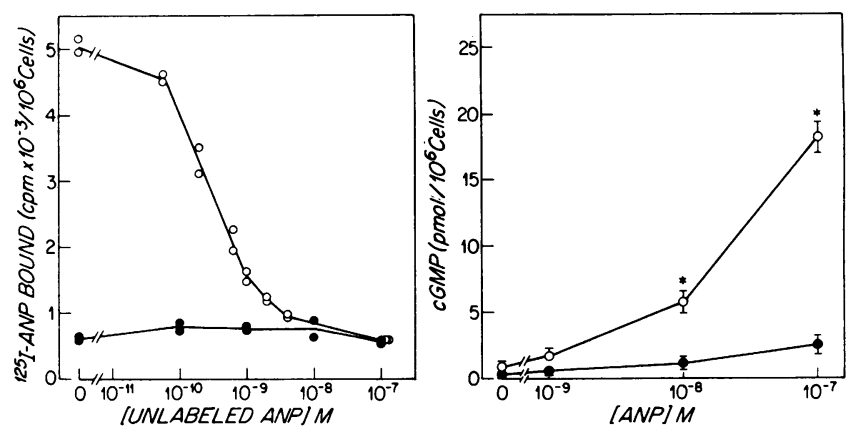

Figure 4. Competitive binding inhibition (left) and ANP-stimulated cGMP generation (right) in glomerular mesangial (o) and epithelial (๑) cells. ${ }^{125}$ I-hANP: $3.12 \times 10^{4} \mathrm{cpm} / \mathrm{ml}$ and $3.00 \times 10^{4} \mathrm{cpm} / \mathrm{ml}$ for mesangial and epithelial cells, respectively. (*) $P<0.01$, epithelial versus mesangial cell cGMP content. 


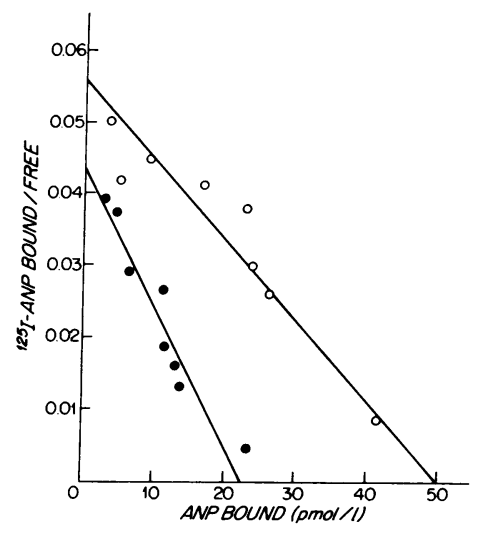

Figure 5. Representative Scatchard plots of competitive binding inhibition data for glomeruli from rats on a low-salt (O) or high-salt (•) diet. ${ }^{125}$ I-hANP concentration, $21.6 \mathrm{pM}$; glomerular protein concentration, 94.6 $\mu \mathrm{g} / \mathrm{ml}(\mathrm{O})$ and $142 \mu \mathrm{g} / \mathrm{ml}$ $(\bullet)$; receptor density, 529 $\mathrm{fmol} / \mathrm{mg} \mathrm{(O)} \mathrm{and} 159 \mathrm{fmol} /$ $\mathrm{mg}$ (•); equilibrium dissociation constant, $K_{\mathrm{d}}, 0.89$ $\mathrm{nM}(0)$ and $0.51 \mathrm{nM}(\bullet)$.

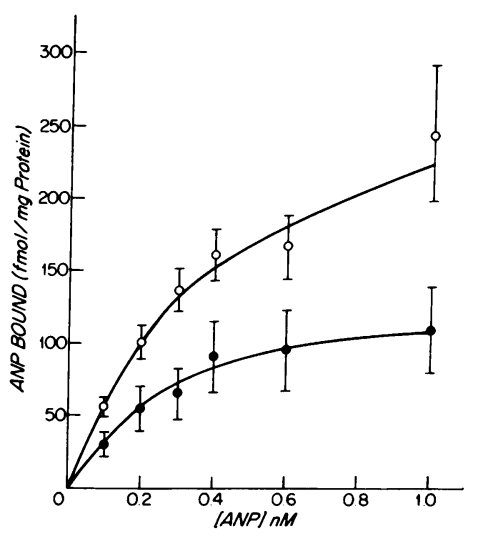

Figure 6. Specific binding of increasing concentrations of ${ }^{125}$ I-hANP (specific activity, $200-250 \mathrm{Ci} / \mathrm{mmol}$ ) to glomeruli from rats given a low-salt (0) or a high-salt (•) diet. ( $n=4 /$ dietary group). are near the true $K_{d}(45)$. Such studies, depicted in Fig. 6, demonstrated that specific hANP binding to glomeruli from rats fed the high salt diet was significantly lower for any given hANP concentration as compared with hANP binding to glomeruli from low-salt rats, consistent with a lower ANP receptor density. Furthermore, binding parameters calculated by Scatchard analysis of these data gave receptor densities of $484 \pm 117 \mathrm{fmol} / \mathrm{mg}$ protein for glomeruli from low-salt rats, and $112 \pm 32 \mathrm{fmol} / \mathrm{mg}$ for high-salt rats with equilibrium dissociation constants of $0.94 \pm 0.29$ and $0.24 \pm 0.07 \mathrm{nM}$, respectively. These values are very similar to those obtained by competition studies. The differences in both parameters between the two salt diets were significant at a confidence level of $95 \%(n=4)$.

To confirm the alterations in ANP receptor affinity with changes in dietary salt intake independent of equilibrium studies, association and dissociation rates for ANP binding to glomeruli from low- and high-salt rats were determined and are shown in Fig. 7. Association rate constants $\left(k_{1}\right)$ were estimated by fitting the binding data to the second-order rate equation $k_{1} t=\left[1 /\left(R_{0}\right.\right.$ $\left.\left.-H_{0}\right)\right] \ln \left[H_{0}\left(R_{0}-B_{t}\right) / R_{0}\left(H_{0}-B_{t}\right)\right]$, where $H_{0}$ is the free ${ }^{125} \mathrm{I}-$ hANP concentration, $R_{0}$ is the receptor concentration, and $B_{t}$ is the concentration of ${ }^{125} \mathrm{I}-\mathrm{h} A N P$-receptor complex at any given time $t$. The receptor density required for each determination was calculated independently by Scatchard analysis of simultaneous competitive binding-inhibition studies. Dissociation rate constants $\left(k_{-1}\right)$ were calculated by fitting the dissociation data to the first-order rate equation $k_{-1} t=\ln \left(B_{t} / B_{0}\right)$, where $B_{0}$ is the concentration of ANP-receptor complex at equilibrium. This transformation of association data at $0^{\circ} \mathrm{C}$ and dissociation data both at $0^{\circ} \mathrm{C}$ and $24^{\circ} \mathrm{C}$ resulted in linear plots, with correlation coefficients in each case of 0.90 or greater, indicating simple second-order and first-order kinetics, respectively. The association rate constants for ANP binding were $2.93 \pm 1.26 \times 10^{5} \mathrm{M}^{-1}$ $\mathrm{s}^{-1}$ in glomeruli from rats fed the low-salt diet $(n=3)$ and $6.39 \pm 1.08 \times 10^{5} \mathrm{M}^{-1} \mathrm{~s}^{-1}$ in glomeruli from rats given the highsalt intake $(n=4)$. Dissociation rate constants were $7.58 \pm 2.43$ $\times 10^{-5} \mathrm{~s}^{-1}(n=3)$ and $3.30 \pm 0.39 \times 10^{-5} \mathrm{~s}^{-1}(n=4)$ for glomeruli from rats fed low- and high-salt diets, respectively. The equilibrium dissociation constant $\left(K_{\mathrm{d}}\right)$, calculated by taking the ratio $k_{-1} / k_{1}$ for each experiment, was significantly higher $(P<0.05)$ in glomeruli from rats fed the low-salt diet, at $0.313 \pm 0.091 \mathrm{nM}$ $(n=3)$ compared with $0.056 \pm 0.011 \mathrm{nM}(n=4)$ for glomeruli from rats given the high-salt diet. To rule out radioligand internalization, ANP dissociation rates were also determined at $24^{\circ} \mathrm{C}$, as shown in the right panel of Fig. 7 for both glomeruli from high- and low-salt rats. ANP dissociation at the higher temper- ature was rapid, and nearly complete $60 \mathrm{~min}$ after the addition of excess unlabeled hANP for the glomeruli from both groups. Dissociation rates at $24^{\circ} \mathrm{C}$ were $6.56 \pm 0.57 \times 10^{-4} \mathrm{~s}^{-1}$ and $7.63 \pm 0.89 \times 10^{-4} \mathrm{~s}^{-1}$ for glomeruli from high- and low-salt rats, respectively $(n=4 /$ group, $P>0.05)$.

Given the differences in glomerular ANP receptor density between high- and low-salt rats, experiments were done to determine whether hANP-stimulated cGMP accumulation also differed. Base-line cGMP content was $0.87 \pm 0.12$ and $0.49 \pm 0.07$ $\mathrm{pmol} / \mathrm{mg}$ protein for glomeruli from high- and low-salt rats, respectively ( $n=11$ /group, $P<0.05)$. Increments in cyclic GMP generation above base-line values in response to hANP did not differ in glomeruli from high- vs. low-salt rats.

Cumulative data for urinary sodium excretion and glomerular ANP receptor density and affinity are given in Table II. 24$\mathrm{h}$ urinary sodium excretion in rats supplemented with $1 \%$ saline drinking water was $6.09 \pm 2.51 \mathrm{mEq}$ as compared with $0.01 \pm 0.001 \mathrm{mEq}$ for rats fed the low-salt diet alone. The mean glomerular ANP receptor density was markedly lower in highsalt rats at $116 \pm 15$ compared with $426 \pm 53 \mathrm{fmol} / \mathrm{mg}$ protein in low-salt rats. A moderately higher glomerular ANP receptor binding affinity was also seen in rats fed the high salt diet, as illustrated by the $K_{d}$ of $0.38 \pm 0.06 \mathrm{nM}$ compared with $0.94 \pm 0.13$ $\mathrm{nM}$ in low-salt rats.

\section{Discussion}

The marked enhancement of renal salt and water excretion by specific atrial peptides provides the attractive hypothesis that

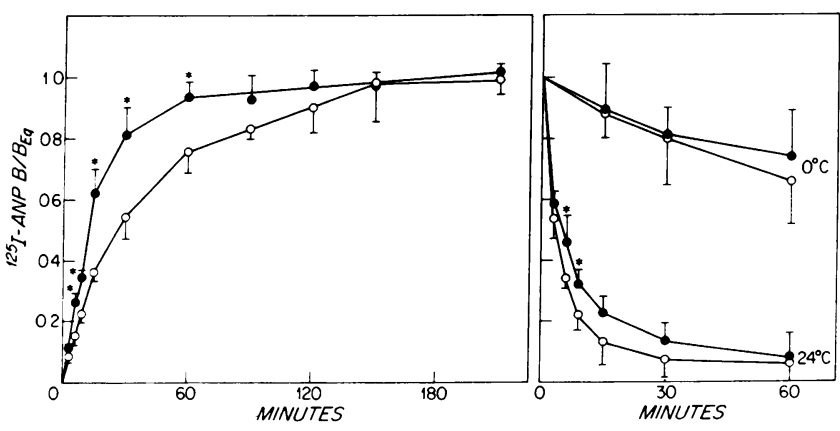

Figure 7. Time-dependence of ${ }^{125} \mathrm{I}-\mathrm{hANP}$ association (left) and dissociation (right) in glomeruli from rats given a low-salt (O) or a high-salt (•) diet ( $n=4$ /dietary group). 
Table II. Urinary Sodium Excretion, Plasma ANP Concentration, and Glomerular ANP Receptor Equilibrium Binding Parameters in High-salt and Low-salt Rats

\begin{tabular}{llll}
\hline Diet & $U_{\mathrm{Na}_{\mathrm{a}} V}$ & $R_{\mathrm{o}}$ & $K_{\mathrm{d}}$ \\
\hline & $m E q / 24 h$ & $\begin{array}{l}\text { fmol/mg } \\
\text { protein }\end{array}$ & $n M$ \\
High-salt & $6.09 \pm 2.51(6)$ & $116 \pm 15(11)$ & $0.38 \pm 0.06(11)$ \\
Low-salt & $0.01 \pm 0.003(6)$ & $426 \pm 53(1)$ & $0.94 \pm 0.13(11)$ \\
& $P<0.001$ & $P<0.001$ & $P<0.001$
\end{tabular}

24-h urinary sodium excretion, $U_{\mathrm{Na}} V$; glomerular ANP receptor density, $R_{0}$; equilibrium dissociation constant, $K_{\mathrm{d}}$; number of rats, $(n)$.

atrial myocytes secrete a volume-regulating hormone. Whether the mechanism of atrial natriuretic peptide (ANP) action depends strictly on changes in renal hemodynamics or requires, in addition, some alteration in renal tubule fluid or ion transport or permeability characteristics is presently unknown. ANP action on glomerular filtration dynamics led us to examine whether isolated glomeruli might exhibit specific receptors for ANP. The accessibility to this portion of the renal vasculature provides an ideal system to study alterations in receptor density and affinity with changes in volume status, and thus by inference, evidence that circulating ANP levels are regulated depending on the degree of volume expansion.

The present study shows that intact renal glomeruli, isolated from normal rats, bind radiolabeled ANP in a specific manner; that is, unlabeled ANP competitively inhibits binding of the radiolabeled ligand at concentrations in the low nanomolar range, whereas the unrelated peptide angiotensin II does not compete for the binding site. Specificity of the binding site is further demonstrated by the findings that ANP analogues known to be physiologically active also compete avidly with the radiolabeled peptide for binding. By contrast, the 13-28 amino acid fragment of ANP does not compete for this binding site, except at concentrations greater than $1 \mu \mathrm{M}$. The basic amino acid sequence for atrial natriuretic peptides is illustrated in Scheme I, with human 1-28 ANP serving as the reference moiety; the other peptides tested for binding and CGMP generation are shown in Table I. Biological activity is thought to reside, in large part, in the ring-structure formed by the disulfide bridge between the two cysteine residues (12). As shown in this study, human 1-28 ANP binds to specific receptors, and stimulates cGMP production in isolated glomeruli. Substitution of isoleucine at position 12 , as is the case for rat 1-28 ANP, does not alter binding or functional potency. The amino-terminal sequence up to the disulfide bridge and the carboxy-terminal tyrosine appear unimportant for receptor binding and cGMP generation in glomeruli, as deletion of these residues does not alter their behavior with respect to binding or CGMP accumulation. Deletion of aminoterminal amino acids through position 12 , however, results in loss of binding and functional activity. The strong correlation between binding and function for the different ANP analogues suggests that specific ANP receptors in isolated glomeruli mediate cGMP generation. Failure of the 13-28 ANP fragment to bind or stimulate cGMP generation further suggests that the ring structure of the molecule is necessary for high-affinity binding. The importance of the disulfide bridge was previously suggested by Misono et al. (12), who demonstrated that biologic activity of ANP could be abolished by reduction and carboxymethylation of the disulfide bridge, and by DeLean et al. (34), who reported that ANP that was reduced by dithiothreitol followed by alkylation with iodoacetamide failed to compete for ${ }^{125} \mathrm{I}-\mathrm{ANP}$ binding to adrenal glomerulosa membranes. The fact that dopamine did not compete for ANP binding in this study would tend to rule out a functional interaction of dopamine with glomerular ANP receptors, or of ANP with dopamine receptors. Inhibition of the functional effects of ANP by the putative dopamine receptor antagonist haloperidol had previously suggested an interaction of dopamine and ANP at the receptor level (46), which this study would not support.

When data from competitive binding inhibition studies in which the unlabeled ANP concentration varied over a wide range $(0.05 \mathrm{nM}-1 \mathrm{M})$ were subjected to computerized analysis, the conclusion was reached that ANP interacts with one population of sites of a single affinity in isolated glomeruli from normal rats. The equilibrium dissociation constant for glomerular ANP binding sites was $0.46 \mathrm{nM}$, similar to values found in previous binding studies in adrenal glomerulosa membranes (34) and with membranes prepared from whole rabbit kidney homogenates and aortic smooth muscle (33). Furthermore, the $K_{d}$ of glomerular ANP binding sites is in the range that would allow interaction with circulating ANP, found in previous reports to be in the range of 20-550 pM (20-22).

Studies with cloned, homogeneous cultures of glomerular mesangial and epithelial cells allow some conclusions to be made with regard to the cell types that express this receptor. Cultured glomerular mesangial cells bind hANP with an affinity nearly identical to that of the glomerular ANP receptor $\left(K_{d}\right.$ of 0.22 $\mathrm{nM}$ ), and manifest $\sim 12,000$ receptors per cell. Mesangial cell ANP receptors are localized to the cell surface, as evidenced by the fact that ${ }^{125} \mathrm{I}-\mathrm{hANP}$ binds to the cells at $4^{\circ} \mathrm{C}$, a temperature too low to allow internalization, and that bound hANP dissociates completely upon acidification of the external medium. Intact glomerular epithelial cells do not bind radiolabeled hANP under conditions identical to those under which mesangial cell binding is demonstrated. The functional response of these two cell types to hANP is in agreement with the binding data, in that the mesangial cells generate significantly more cGMP in response to hANP than glomerular epithelial cells. The fact that the functional response in glomerular epithelial cells is not completely absent may indicate that a small number of ANP binding sites are present on these cells, but that their density is too low to be detected with the radioligand binding assay. Although unlikely, the alternate possibility, that the cGMP response is not receptor mediated, but that lower responsiveness of epithelial cells reflects lower concentrations of guanylate cyclase, cannot be ruled out. From the experimental evidence in this study, it can be concluded that glomerular mesangial cells are likely to express ANP receptors in vivo, whereas glomerular epithelial cells probably do not. This is not unexpected, as ANP is known to interact with other vascular and with nonvascular smooth muscle, causing relaxation (26-28), whereas physiologic ANP effects on epithelia are not regularly found $(24,25)$. Whether glomerular endothelial cells manifest ANP receptors remains to be determined.

Changes in the ambient concentrations of many hormones are commonly associated with reciprocal changes in the density of their specific receptors in target tissues $(47,48)$. To determine whether the glomerular ANP receptor density is similarly regulated, we chose to study two extremes of salt intake, which 
were expected to maximize possible differences. Glomerular ANP receptor density was found to be markedly greater in rats fed a low-salt diet for 10-14 d, as compared with rats given a high-salt diet. These findings imply that rats on low sodium diets have little stimulus to secrete ANP, and thus glomerular ANP receptor upregulation occurs. Since manipulation of dietary salt intake resulted not only in changes in receptor density but also in receptor affinity, it was necessary to assess these two parameters independently, as competitive binding inhibition studies can be associated with artificial shifts in the apparent $K_{d}(45)$. The finding that specific ANP binding to glomeruli from low-salt rats was greater than that to glomeruli from high-salt rats, when glomeruli were incubated with increasing concentrations of radiolabeled hANP, despite an apparently lower affinity (Fig. 6) can only be explained by an increase in receptor density, and thus confirms that low-salt feeding is associated with upregulation of glomerular ANP receptor density. Estimation of glomerular ANP receptor affinity by kinetic studies shows that the receptor affinity is significantly higher in glomeruli from rats given a high-salt diet, compared with those given a low-salt diet, and confirms the results for receptor affinity observed with equilibrium binding studies. The equilibrium dissociation constants $\left(K_{d}\right)$ for the ANP receptor were somewhat lower when calculated from kinetic data compared with equilibrium studies. This is probably explained by the exceedingly slow dissociation of ANP from its receptor at $0^{\circ} \mathrm{C}$, which makes precise determination of the dissociation rate constants difficult. Since binding was rapidly and completely reversible at $24^{\circ} \mathrm{C}$, the slow dissociation rates at the lower temperature could not be ascribed to receptor or ligand internalization. The lowering of glomerular ANP receptor affinity with low-salt feeding would tend to oppose increased ANP binding due to augmentation of receptor density. The experiments in this study show, however, that the increment in receptor density outweighs the reduction in affinity in low-salt rats, as hANP binding to glomeruli from low-salt rats is greater at any given hANP concentration despite the lower affinity (Fig. 6).

Previous studies have shown that ANP stimulates membraneassociated guanylate cyclase activity (37), and it has been postulated that this enzyme may be directly activated by ANP receptor occupancy (37). In the present study, the concentrationdependent stimulation by hANP of cyclic GMP generation did not differ between glomeruli from rats on a low salt diet compared with the high salt diet despite markedly enhanced binding of hANP to glomeruli from low-salt rats. If stimulation of guanylate cyclase activity were the primary event evoked by agonist occupancy of ANP receptors, it would have been expected that cyclic GMP accumulation be greater in glomeruli from low-salt rats, just as hANP binding was greater. Furthermore, primary cellular responses that are directly linked to a hormone receptor are generally maximal at concentrations of agonist that saturate the receptor, or as is frequently the case, at agonist concentrations that occupy only a small fraction of receptors (49). In this case, however, the physiologic response (cGMP accumulation) is detected only at concentrations of hANP that far exceed those required for receptor binding. This type of dose-response curve, the failure of an increased functional response in the face of increased receptor density, and reports of circulating ANP concentrations one to two orders of magnitude below those required for cGMP accumulation $(20,21)$, suggest that stimulation of guanylate cyclase activity in response to ANP, although receptormediated, is a secondary phenomenon, as is the case for the stimulation of guanylate cyclase activity by other hormones (50).
In conclusion, the present study demonstrates that intact rat renal glomeruli exhibit specific receptors for ANP. ANP receptors are expressed on cultured glomerular mesangial, but not epithelial cells. The ANP binding site in glomeruli and in mesangial cells is at the cell surface, as binding was completely reversible. The amino-terminal sequence of ANP up to the disulfide bridge, and the carboxy-terminal tyrosine are not required for receptor binding or for cyclic GMP stimulation; furthermore, ANP is equally active if methionine or isoleucine is present at position 12. Although binding of ANP to the specific receptor appears necessary to stimulate cyclic GMP generation, the findings in this study suggest that guanylate cyclase is not coupled directly to this ANP receptor. Finally, the reciprocal regulation of glomerular ANP receptor density with alterations in dietary salt intake, suggests that ANP is a circulating hormone that participates in the regulation of extracellular fluid volume.

\section{Acknowledgments}

We are grateful to Ms. Donna McDermott for expert secretarial assistance.

This work was supported by National Institutes of Health grants AM 30410, HL-01194, HL-26191, and AM-13132.

\section{References}

1. Jamieson, J. D., and G. E. Palade. 1964. Specific granules in atrial muscle. J. Cell Biol. 23:151-172.

2. De Bold, A. J. 1979. Heart atria granularity effects of changes in water-electrolyte balance. Proc. Soc. Exp. Biol. Med. 161:508-511.

3. De Bold, A. J., H. B. Borenstein, A. T. Veress, and H. Sonnenberg. 1981. A rapid and potent natriuretic response to intravenous injection of atrial myocardial extract in rats. Life Sci. 28:89-94.

4. Pollock, D. M., and R. O. Banks. 1983. Effect of atrial extract on renal function in the rat. Clin. Sci. (Lond.). 65:47-55.

5. Beasley, D., and R. L. Malvin. 1985. Atrial extracts increase glomerular filtration rate in vivo. Am. J. Physiol. 248:F24-F30.

6. Burnett, J. C., Jr., J. P. Granger, and T. J. Opgenorth. 1984. Effects of synthetic atrial natriuretic factor on renal function and renin release. Am. J. Physiol. 247:F863-F866.

7. Baines, A. D., A. J. De Bold, and H. Sonnenberg. 1983. Natriuretic effect of atrial extract on isolated perfused kidney. Can. J. Physiol. Pharmacol. 61:1462-1466.

8. Camargo, M. J. F., H. D. Kleinert, S. A. Atlas, J. E. Sealey, J. H. Laragh, and T. Maack. 1984. Ca-dependent hemodynamic and natriuretic effects of atrial extract in the isolated perfused kidney. Am. J. Physiol. 246:F447-F456.

9. Misono, K. S., R. T. Grammer, H. Fukumi, and T. Inagami. 1984. Rat atrial natriuretic factor: isolation, structure and biological activities of four major peptides. Biochem. Biophys. Res. Commun. 123:444-451.

10. Kanagawa, K., A. Fukuda, I. Kubota, Y. Hayashi, and H. Matusuo. 1984. Identification in rat atrial tissue of multiple forms of natriuretic polypeptides of about 3,000 daltons. Biochem. Biophys. Res. Commun. 121:585-591.

11. Seidman, S. E., K. D. Bloch, K. A. Klein, J. A. Smith, and J. G. Seidman. 1984. Nucleotide sequences of the human and mouse atrial natriuretic factor genes. Science (Wash. DC). 226:1206-1209.

12. Misono, K. S., H. Fukumi, R. T. Grammer, and T. Inagami. 1984. Rat atrial natriuretic factor: complete amino acid sequence and disulfide linkage essential for biological activity. Biochem. Biophys. Res. Commun. 119:524-529.

13. Oshima, T., M. G. Currie, D. M. Geller, and P. Needleman. 1984. An atrial peptide is a potent renal vasodilator substance. Circ. Res. 54:612-616.

14. Zivin, R. A., J. H. Condra, R. A. Dixon, N. G. Seidah, M. Chr'etien, M. Nemer, M. Chamberland, and J. Drouin. 1984. Molecular 
cloning and characterization of DNA sequences encoding rat and human atrial natriuretic factors. Proc. Natl. Acad. Sci. USA. 81:6325-6329.

15. Kanagawa, K., Y. Tawaragi, S. Oikawa, A. Mizuno, Y. Sakuragawa, H. Nakazato, A. Fukuda, N. Minamino, and H. Matsuo. 1984. Identification of rat gamma atrial natriuretic polypeptide and characterization of the cDNA encoding its precursor. Nature (Lond.). 312:152155.

16. Greenberg, B. D., G. H. Bencen, J. J. Seilhamer, J. A. Lewicki, and J. C. Fiddes. 1984. Nucleotide sequence of the gene encoding human atrial natriuretic factor precursor. Nature (Lond.). 312:656-658.

17. Nemer, M., M. Chamberland, D. Sirois, S. Argentin, J. Drouin, R. A. Dixon, R. A. Zivin, and J. H. Condra. 1984. Gene structure of human cardiac hormone precursor, pronatriodilatin. Nature (Lond.). 312: 654-656.

18. Veress, A. T., and H. Sonnenberg. 1984. Right atrial appendectomy reduces the renal response to acute hypervolemia in the rat. $\mathrm{Am}$. J. Physiol. 247:R610-R613.

19. Dietz, J. R. 1984. Release of natriuretic factor from rat heartlung preparation by atrial distension. Am. J. Physiol. 247:R1093-R 1096 .

20. Lang, R. E., H. Tholken, D. Ganten, F. C. Luft, H. Ruskoaho, and T. Unger. 1985. Atrial natriuretic factor-a circulating hormone stimulated by volume loading. Nature (Lond.). 314:264-266.

21. Gutkowska, J., K. Horky, G. Thibault, P. Januszewicz, M. Cantin, and J. Genest. 1984. Atrial natriuretic factor is a circulating hormone. Biochem. Biophys. Res. Commun. 125:315-323.

22. Tanaka, I., K. S. Misono, and T. Inagami. 1984. Atrial natriuretic factor in rat hypothalamus, atria and plasma: determination by specific radioimmunoassay. Biochem. Biophys. Res. Commun. 124:663-668.

23. Sonnenberg, H., W. A. Cupples, A. J. De Bold, and A. T. Veress. 1982. Intrarenal localization of the natriuretic effect of cardiac atrial extract. Can. J. Physiol. Pharmacol. 60:1149-1152.

24. Baum, M. 1985. Effect of atrial natriuretic factor on the rabbit proximal convoluted tubule. Clin. Res. 33:477a (Abstr).

25. Umemura, S., D. D. Smyth, and W. A. Pettinger. 1985. Effect of atrial natriuretic factor or $\alpha 2$-adrenoceptor stimulation on cyclic AMP levels in single nephron segments. Fed. Proc. 44:1102 (Abstr).

26. Currie, M. G., D. M. Geller, B. R. Cole, J. G. Boylan, W. YuSheng, S. W. Holmberg, and P. Needleman. 1983. Bioactive cardiac substances: potent vasorelaxant activity in mammalian atria. Science (Wash. DC). 221:71-73.

27. Garcia, R., G. Thibault, M. Cantin, and J. Genest. 1984. Effect of a purified atrial natriuretic factor on rat and rabbit vascular strips and vascular beds. Am. J. Physiol. 247:R34-R39.

28. Ohlstein, E. H., and B. A. Berkowitz. 1985. Cyclic guanosine monophosphate mediates vascular relaxation induced by atrial natriuretic factor. Hypertension. 7:306-310.

29. Tang, J., R. J. Webber, D. Chang, J. K. Chang, J. Kiang, and E. T. Wei. 1984. Depressor and natriuretic activities of several atrial peptides. Regul. Pept. 9:53-59.

30. Mack, T., D. N. Marion, M. J. F. Camargo, H. D. Kleinert, J. H. Laragh, E. D. Vaughan, Jr., and S. A. Atlas. 1984. Effects of auriculin (atrial natriuretic factor) on blood pressure, renal function, and the reninaldosterone system in dogs. Am. J. Med. 77:1069-1075.

31. Huang, C.-L., J. Lewicki, L. K. Johnson, and M. G. Cogan. 1985. Renal mechanism of action of rat atrial natriuretic factor. J. Clin. Invest. 75:769-773.

32. Ichikawa, I., B. R. Dunn, J. L. Troy, T. Maack, and B. M. Brenner.
1985. Influence of atrial natriuretic peptide on glomerular microcirculation in vivo. Clin. Res. 33:487a (Abstr).

33. Napier, M. A., R. L. Vandlen, G. Albers-Schonberg, R. F. Nutt, S. Brady, T. Lyle, R. Winquist, E. P. Faison, L. A. Heinel, and E. H. Blaine. 1984. Specific membrane receptors for atrial natriuretic factor in renal and vascular tissues. Proc. Natl. Acad. Sci. USA. 81:5946-5950.

34. DeLean, A., J. Gutkowska, N. McNicoll, P. W. Schiller, M. Cantin, and J. Genest. 1984. Characterization of specific receptors for atrial natriuretic factor in bovine adrenal zona glomerulosa. Life Sci. 35:23112318.

35. Leitman, D. C., S. A. Waldman, T. Kuno, and F. Murad. 1985. Specific atrial natriuretic factor receptors mediate increased cyclic GMP accumulation in cultured bovine aortic endothelial and smooth muscle cells. Clin. Res. 33:599a (Abstr).

36. Hamet, P., J. Tremblay, S. C. Pang, R. Garcia, G. Thibault, J. Gutkowska, M. Cantin, and J. Genest. 1984. Effect of native and synthetic atrial natriuretic factor on cyclic GMP. Biochem. Biophys. Res. Commun. 123:515-527.

37. Waldman, S. A., R. M. Rapoport, and F. Murad. 1984. Atrial natriuretic factor selectively activates particulate guanylate cyclase and elevates cyclic GMP in rat tissues. J. Biol. Chem. 259:14332-14334.

38. Misra, R. P. 1972. Isolation of glomeruli from mammalian kidneys by graded sieving. Am. J. Clin. Pathol. 58:135-139.

39. Lowry, O. H., N. J. Rosebrough, A. L. Farr, and R. J. Randall. 1951. Protein measurement with the Folin phenol reagent. J. Biol. Chem. 193:265-275.

40. Kreisberg, J. I., and M. J. Karnovsky. 1983. Glomerular cells in culture. Kidney Int. 23:439-447.

41. Harper, P. A., J. M. Robinson, R. L. Hoover, T. C. Wright, and M. J. Karnovsky. 1984. Improved methods for culturing rat glomerular cells. Kidney Int. 26:875-880.

42. Cereijido, M., E. S. Robbins, W. J. Dolan, C. A. Rotunno, and D. D. Sabatini. 1978. Polarized monolayers formed by epithelial cells on a permeable and translucent support. J. Cell Biol. 77:853-880.

43. Scatchard, G. 1949. The attractions of proteins for small molecules and ions. Ann. N.Y. Acad. Sci. 51:660-672.

44. Munson, P. J., and D. Rodbard. 1980. LIGAND: a versatile computerized approach for characterization of ligand binding systems. Anal. Biochem. 107:220-239.

45. Jacobs, S., K.-J. Chang, and P. Cutrecasas. 1975. Estimation of hormone receptor affinity by competitive displacement of labeled ligand: effect of concentration of receptor and of labeled ligand. Biochem. Biophys. Res. Commun. 66:687-692.

46. Marin-Grez, M., G. Schubert, J. P. Briggs, and J. Schnermann. 1985. Inhibition by haloperidol of the natriuresis induced by atrial natriuretic factor. Kidney Int. 27:261 (Abstr).

47. Lefkowitz, R. J., and T. Michel. 1983. Plasma membrane receptors. J. Clin. Invest. 72:1185-1189.

48. Gunther, S., M. A. Gimbrone, Jr., and R. W. Alexander. 1980. Regulation by angiotensin II of its receptors in resistance blood vessels. Nature (Lond.). 287:230-232.

49. Levitzki, A. 1980. Quantitative aspects of ligand binding to receptors. In Cellular Receptors for Hormones and Neurotransmitters. D. Schulster and A. Levitzki, editors. John Wiley \& Sons, Inc., New York. 9-28.

50. Goldberg, N. D., and M. K. Haddox. 1977. Cyclic GMP metabolism and involvement in biological regulation. Annu. Rev. Biochem. 46:823-896. 